\section{Cover-cropping Practices of Vegetable Producers in Western New York}

\author{
Lydia J. Stivers-Young ${ }^{1}$ and \\ Frances A. T ucker ${ }^{2}$
}

AdDitional INDEX WORDS. oats (A vena sativa), rye (Secale cereale), clover (Trifoli um pratense), sudangrass (Sorghum sudanens), barley (H ordeum vulgare), hairy vetch (Vicia villosa), ryegrass (Loli um multiflorum), wheat (Tritiaum aestivum), alfalfa (Medi cago sativa)

Summary. Surveys of vegetable growers in a six-county region in western $\mathrm{New}$ York were conducted in 1997 to determine which cover cropping practices were being used on commercial vegetable operations; to identify producers' needs for further research and information, and to assess the impact of cooperative extension programs in this area. In a broad survey, 118 responses were returned out of 315 surveys sent (37\%). Respondents represented $>37,000$ acres (14974 ha) of vegetable production, or $\approx 53 \%$ of the vegetable acreage in the region. Vegetable acreage per operation ranged from 1 to 4000 acres (0.4 to 1619 ha). Sixty-nine percent responded that they grew cover crops on a total of 15,426 acres (6243 ha). 0 ats (A vena sativa L.), rye (Secale cereale), clover (Trifolium pratense), and wheat (Triticum vulgare) were the most commonly used cover crops. Seventysix percent of the reported covercropped acres were planted to small grains, and $19 \%$ to legumes, almost entirely clovers. In open ended questions, the most important benefits

Cornell Cooperative Extension, $249 \mathrm{H}$ ighland Ave. Rochester, NY 14620

We thank the vegetable producers who responded to our survey; and Tom Lyson, Steve Reiners, and J erry Bond for reviewing the manuscript. The cost of publishing this paper was defrayed in part by the payment of page charges. U nder postal regulations, this paper therefore must be hereby marked advertisement solely to indicate this fact.

${ }^{1}$ A rea extension specialist.

${ }^{2}$ Program assistant

Hortlechnology • July-September 1999 9(3) of cover cropping identified by respondents were erosion control $(46 \%$ of respondents) and organic matter additions (42\%). The most important problems associated with cover crops were that they interfere with spring field work or fall harvest (26\%), and that they are difficult to incorporate or plow under (24\%). A targeted survey of nineteen onion (Alli um cepa $L_{\text {.) }}$ producers in the same region measured the recent adoption of sudangrass (Sorghum sudanense Piper) and sorghum-sudan hybrid (Sorghum bi color L. x S. sudanens) cover crops, the focus of the several years of extension research and educational programs. $\mathrm{N}$ ine of the onion producers had adopted the practice, and six of these had done so since the beginning of these extension programs. The implications of these results for research and extension are discussed.

A gricultural science literature is filled with reports on the beneficial aspects of cover cropsin farming systems, both for environmental conservation and for improving and maintaining productivity (Bruce et al., 1991; D rinkwater et al., 1998; M eisinger et al., 1991; Staver and Brinsfield, 1998). Thecoreof thisknowledge is not new; the ancient Romans understood the importance of rotating edible crops with forage legumes. Field studies in E uropeand the U nited States after the turn of the century began to provide a scientific basis for promoting the practice (Barron, 1925; Pieters, 1927), and the dustbowls of the 1930s underscored the importance of vegetativecover for cultivated land. L essattention was paid to cover crops with the advent of chemical fertilizers after World War II. But since the mid-1980s, increased interest in the sustainability of agriculture has spawned a great deal of research in expanding the use of cover crops in existing and evolving production systems, especially those involving conservation tillage(Blevinsetal., 1990; Sainju and Singh, 1997).

Cover cropping is particularly appropriate for vegetable production systems which typically leave few surface residuesforerosion protection (Bellinder and Gaffney, 1995), return little organic matter to soils, and are often associated with soil structural problems that can severely limit productivity (Wolfeet al., 1995). Cover cropscan be used to help mitigatethese problems, as well as to manage pest such asweedsand diseases (Creamer et al., 1995; Viane and Abawi, 1998). H owever, somecover cropscan exacerbatevegetablepest problems (G.S. Abawi, personal communication). Climate and geography can be important factors determining covercropping practices of vegetable producers. Growers in the northeastern U.S. are somewhat limited in their covercropping options by a short growing season (Stivers-Young, 1998).

Growers often take many diverse factors into account when making management decisions such as what types of cover cropsto grow, how much acreage to devote to cover crops, and how to manage them. As new information becomes available on the benefits of cover cropping, on new cover crop species or cultivars, and on successful methodsfor managing cover crops, it is useful to document the actual practices of growers, as well as their reasons for adopting or not adopting cover crops. Thisinformation can be used to direct or refine research, and to identify opportunities for extending current knowledge.

In thisstudy, commercial vegetable producersin six western $\mathrm{N}$ ew York counties were surveyed about their cover cropping practices, and perceived benefits and drawbacks of cover cropping. Theobjectiveswereto determinewhich cover-cropping practicesand speciesare being used on commercial operations; to identify producers' needs for further research and information; and to measure the impact of cooperative extension programs in this area.

\section{Materials and methods}

O ne broad and one targeted survey of commercial vegetable growers in a six-county area in western N ew York were conducted in 1997. The broad survey was a questionnaire consisting of both multiple choice and open ended questions (Table 1 ), and was mailed to 315 commercial vegetable growers enrolled in cooperative extension in M onroe, G enesee, O rleans, N iagara, Erie, and Chautauqua counties. These six counties lie along the southern shore of Lake $O$ ntario and eastern shore of $L$ ake Erie, and contain $>70,000$ acres of commercial vegetables, $\approx 35 \%$ of the state's total vegetable acreage (U.S. D ept. of Commerce, 1992). A single mailing was done on $17 \mathrm{~N} \mathrm{ov}$. 1998, and responses were collected for a period of 8 weeks after the mailing.

$\mathrm{N}$ o definition of cover crops was included in the survey, allowing respon- 
T able 1. Q uestionnaire for survey of cover cropping practices of vegetable producers in western $\mathrm{N}$ ew York.

1. Please record your yearly average acreage of all vegetables (including dry beans).

2. Please check which of the following vegetable crops you grow:

cabbage

sweet corn, fresh peppers

sweet corn, processing pumpkins

snap beans, fresh cucumbers, melons, squash

peas lettuce or leafy greens

beets or carrots potatoes

dry beans onions

3. D o you currently use cover crops in your vegetable rotation? Yes (go to \#5) No (go to \#4)

4. If you checked no in \#3, please rate your interest level in the use of cover crops: Will probably use soon Might use; some interest

5. If you checked yes in \#3, then:

M ight use; some interest $\quad \quad N$ ot interested

A. When did you start using cover crops? before 1990

between 1990-95

since 1995

B. Which cover crop(s) do you currently use? If you use more than one, please estimate the acreage of each cover crop planted:

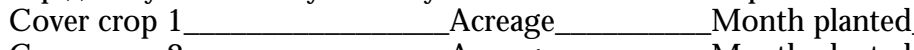

Cover crop 2 2

6. Please list the top three benefits and the three problems you see to using cover crops in your operation:

7. H ow useful to you is Cornell Cooperative Extension as a source of information about cover crops?

Very useful Somewhat useful N ot useful

8. Do you have questions about cover crops which you would like to see addressed in the future? $\mathrm{H}$ ow might this information best be conveyed to you:

Grower meeting

Bulletin
N ewsletter article

0 ther (please describe)

9. Additional comments:

dents to rely on their own definitions. $\mathrm{N}$ o mention was made in the survey of specific cover crop species, nor of particular benefits or problems associated with cover cropping.

A smaller, targeted survey of onion growers in O rleans and G enesee counties was conducted during the same months. There are $\approx 2500$ acres ( 1012 ha) of onions grown on muck (organic) soils in these two counties, representing a crop value of over $\$ 8$ million ( $\mathrm{N}$ ew York Agricultural Statistics Service, 1997). Thesurvey wasfirst mailed to all sixteen onion growers in the area, and nonrespondents were later contacted by phone or by a personal visit. This survey asked the following questions: "D o you grow sudangrassor sorghumsudangrasshybrid cover crops?" "If yes, how many acres this year?" and "What was the first year you grew this cover crop?" The specific objective of this smaller survey was to measure the adoption of one cover-cropping practice, using sudangrass and sorghum-sudan hybrid cover cropsin rotation with muckgrown onions. Research hasshown that these cover crops can improve subsequent onion crop yields by breaking pest life cycles and improving soil structure (M ishanec, 1998). This practice had been the topic of numerous research projects, demonstrations, and educational programs conducted by
Cornell Cooperative Extension during the years 1993-97.

\section{Results}

In the larger survey, 118 responses were returned out of 315 surveys sent, for a $35 \%$ response rate. H owever, respondents represented 37,093 acres $(15,012 \mathrm{ha})$ of vegetable production, or $53 \%$ of the commercial vegetable acreage in thesix-county region. Potatoes (Solanum tuber osum L.) and edible dry beans (Phaseolus vulgaris L.) are both considered vegetables for purposes of this study. In the smaller survey, answers to questions were obtained from eighteen of the nineteen onion growers.

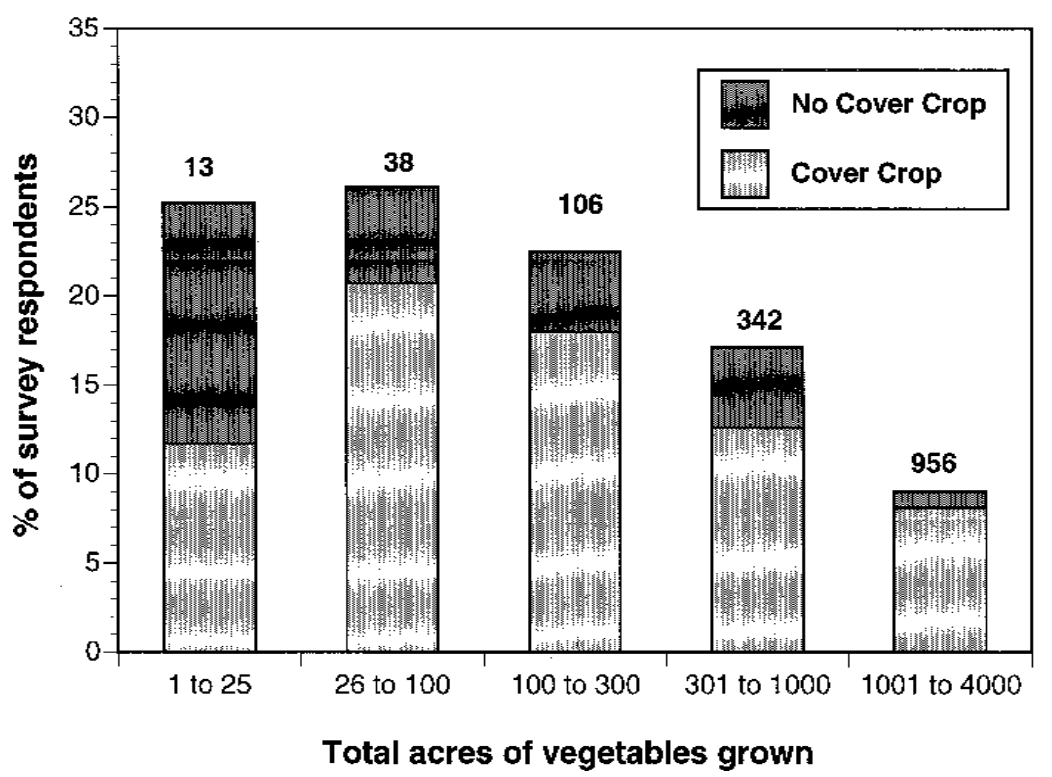

Fig. 1. The frequency distribution of respondents per size class of total vegetable acreage is shown by columns. Each column is divided into self-identified cover crops growers (dark portion) and noncover crops growers (light portion). N umbers on top of columns indicate the average cover cropped acreage, for those who do cover crop, within each size class of vegetable acreage ( 1 acre $=0.405 \mathrm{ha}$ ). 


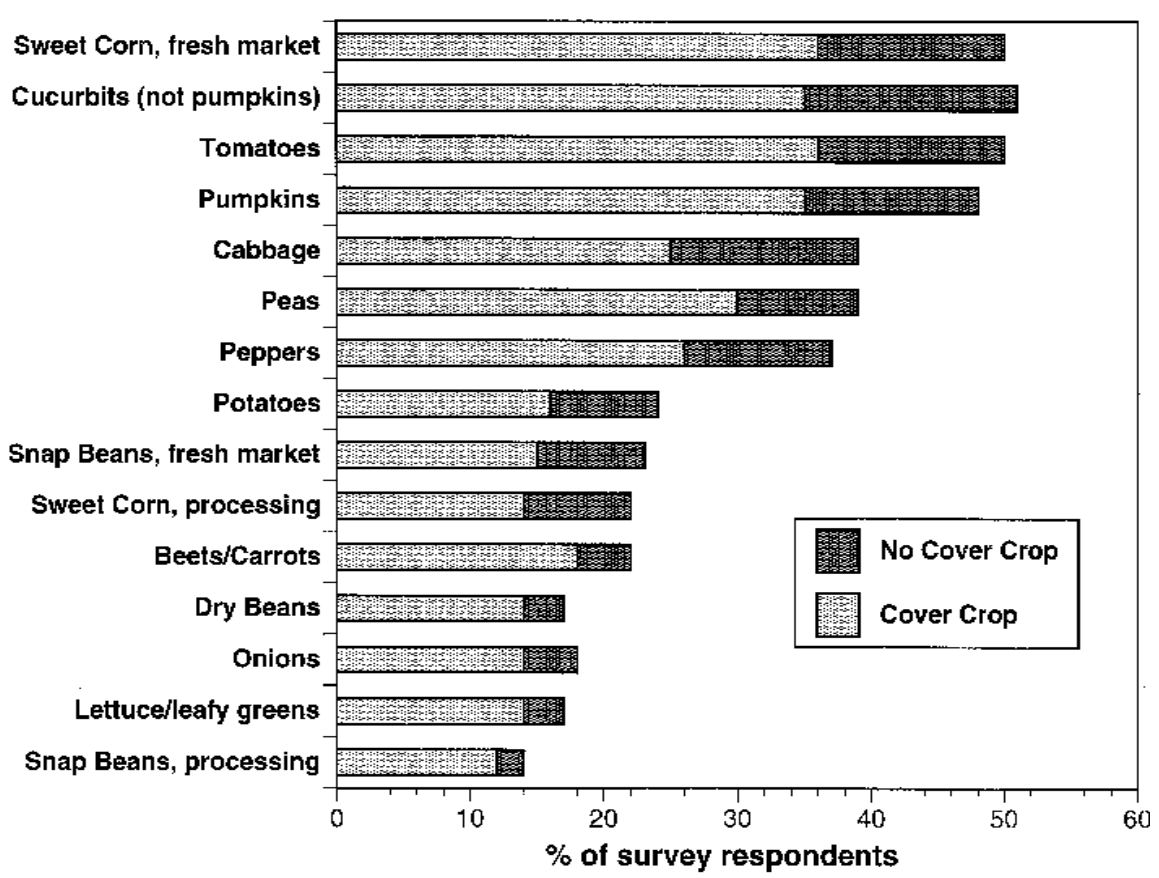

Fig. 2. F requency distribution of specific vegetable crops grown by respondents is shown by columns. Each column is divided into self-identified cover crops growers (dark portion) and noncover crops growers (light portion).

Characteristics of respondents. Respondents to the larger survey represented a wide range of vegetable operation sizes, from a minimum of 1 acre (0.4 ha) to a maximum of 4000 acres (1619 ha) of commercial vegetable production (Fig. 1). Just over half of respondents produce 100 acres ( $40.5 \mathrm{ha}$ ) of vegetables or less, and $9 \%$ produce $>1000$ acres ( $405 \mathrm{ha}$ ).

Consistent with the wide range of acreage, respondents produce a wide variety of vegetable crops (Fig. 2). In this region, vegetables are produced for processing markets [peas (Pisum sativum var. arvense L.), sweet corn (Zea mays var. rugosa Bonaf.), snap beans (Phaseolus vulgaris L.), potatoes, beets (Beta vulgaris L. Crassa group), carrots (D aucus carota L.), and dry edible beans], for storage [ potatoes, onions, cabbage (Brassica ol eracea L. Capitata group)], and for fresh market wholesaleand direct marketing channels [ primarily sweet corn, cucurbits, tomatoes (Lycopersicon es culentum Mill), peppers (Capsicum annuum var. annuum L.), and various other vegetables]. The vegetables grown by the highest number of respondents, including fresh market sweet corn, tomatoes, pumpkins (Curcurbita pepo L. var. pepo) and other vine crops, are all important fresh market crops. Producers grow-
25 or fewer acres (10 ha) cover crop, while $90 \%$ of those with $>1000$ acres (405 ha) grow cover crops.

The proportion of respondents who grow specific vegetable crops and who also grow cover crops is shown in Fig. 2. However, this data does not indicate whether or not cover cropsare grown specifically for the benefit of, or in rotation with, each specific vegetable crop. The percent of producers who grow specific vegetablecropswho also grow cover crops ranged from $61 \%$ (processing sweet corn) to $87 \%$ (processing snap beans). N o class of vegetable crops (processing, storage, or fresh market) tended to show obvious higher or lower rates of cover cropping.

Growers reported planting cover crops on a total of 15,426 acres ( 6243 ha; Table 2). Because the terms vegetable crops and cover crops were selfdefined, the total cover-cropped acreage is not simply a subset of the total vegetable acreage. In some cases, growers responded that they grew more acres of cover cropsthan of vegetables, indicating that either they did not consider the cover-cropped acreage part of their vegetable acreage, or that they were reporting cover crops grown for vegetables as well as other crops.

$O$ at cover crops were the highest in terms of acres planted, followed by grain rye, red clover, and wheat. Rye was planted by the largest number of growers (44), followed by wheat, red clover, and oats. The largest acreages of cover crops per operation were rye [ 1300 acres ( 526 ha) ] and oats [ 1250 acres (506 ha) ].

Seventy-six percent of the total reported cover-cropped acres were planted in the small grain crops of rye, oats, wheat, and barley ( $\mathrm{H}$ ordeum vulgare L.). L egumes [red clover, alfalfa (M edicago sativa L.), and rye plus hairy vetch (Vicia villosa Roth)] were planted on $19 \%$, with the remaining $5 \%$ in sudangrass, ryegrass (Lolium multiflorum Lam.), and buckwheat (Fagopyrum esculentum M oench) combined. Sudangrass and sorghum sudangrasshybridsconstituted lessthan $3 \%$ of the cover cropped acres, but were grown by $10 \%$ of respondents.

$\mathrm{O}$ ats, rye and wheat are planted most frequently in September and $O$ ctober, and cloversare planted mostly in $\mathrm{M}$ arch and April (T able 2). About $80 \%$ of the acreage is planted to cover crops which grow primarily in fall, 
T able 2. C over crops grown on commercial vegetable operations in western $\mathrm{N}$ ew York.

\begin{tabular}{|c|c|c|c|c|c|c|}
\hline $\begin{array}{l}\text { Cover } \\
\text { crop }\end{array}$ & $\begin{array}{c}\text { Acres } \\
\text { planted }^{\mathbf{2}}\end{array}$ & $\begin{array}{c}\text { Cover cropped } \\
\text { acreage } \\
(\%)\end{array}$ & $\begin{array}{c}\text { G rowers } \\
\text { (no.) }\end{array}$ & $\begin{array}{c}\text { Mean } \\
\text { acres/ }^{-1} \\
\text { G rower }^{y}\end{array}$ & $\begin{array}{c}\text { R ange } \\
\text { (acres) }^{z}\end{array}$ & $\begin{array}{l}\text { Months } \\
\text { planted }^{\mathrm{x}}\end{array}$ \\
\hline$O$ ats & 4007 & 26.0 & 18 & 236 & $1-1250$ & $7,8,9,10,11$ \\
\hline Rye (grain) & 3727 & 24.2 & 44 & 89 & $2-1300$ & $7,8, \mathbf{9}, \mathbf{1 0}, 11$ \\
\hline Clovers & 2728 & 17.7 & 19 & 152 & $7-700$ & $2,3,4,5$ \\
\hline Wheat & 2640 & 17.1 & 22 & 125 & $1-500$ & $7,8, \mathbf{9}, \mathbf{1 0}, 11$ \\
\hline Barley & 1374 & 8.9 & 9 & 172 & $50-650$ & $\mathbf{4}, 5,7, \mathbf{8}, \mathbf{9}, 10$ \\
\hline Sudangrass ${ }^{w}$ & 414 & 2.7 & 12 & 35 & $3-100$ & $5,6,7$ \\
\hline Ryegrass & 338 & 2.2 & 5 & 68 & $8-200$ & 8,9 \\
\hline Alfalfav & 99 & 0.6 & 5 & 20 & $6-60$ & $4,5,8$ \\
\hline Rye and hairy vetch & 95 & 0.6 & 2 & 47 & $40-55$ & $8,9,10$ \\
\hline Buckwheat & 4 & $<0.1$ & 2 & 2 & $1-3$ & $6,7,8$ \\
\hline Total & 15,426 acres & & $81^{u}$ & & & \\
\hline
\end{tabular}

z1 acre $=0.405$ ha.

yA verage size of planting, in acres, based on number of growers who supplied acreage information.

xM onths in which growers reported planting cover crop ( 1 = January, 2 = February, etc.). M onths shown in bold were those most frequently indicated.

wincludes sorghum-sudangrass hybrids.

vSelf-described as using alfalfa as a cover crop. It is likely that this is only a small proportion of the total acreage of alfalfa planted by this group of growers, most of whom do not consider it a cover crop per se.

u $\mathrm{O}$ a total of 118 responses, 81 producers indicated that they do grow cover crops.

winter, and early spring. Of the cover crops identified by respondents, only clover and sudangrass, representing $20 \%$ of the acreage, are grown primarily during the summer months. Clover is often left to grow for an entire year.

Therelationship between thevegetable crops and the major cover crops grown by respondents is shown in Table 3. In general, wheat tends to be favored by processing vegetable and cabbage producers; rye is favored by fresh market vegetable producers; clovers by dry bean and processing sweet corn growers. Barley is grown mostly by onion producers.

BenefiTs AND PROBLEMS IDENTIFIED. Both cover-crop growers and nongrowersresponded to survey ques- tions about benefits and problems of cover cropping. Benefits and problems identified by producers were grouped into similar responses ( $T$ ables 4 and 5). There is some overlap in these response classes, but attention was paid to maintaining the emphasis of each response when grouping them. The most important benefits of growing cover crops cited were erosion control (both wind and water erosion) and adding organic matter. Weed suppression and the addition or conservation of nutrients were also frequently noted benefits although few identified reduction of insect and disease pressure as significant. Benefitsin the areas of soil structure (soil tilth, soil compaction, and drainage) were also important.
While there were a total of 219 responses to the benefits question, the question on problems associated with cover cropping elicited only 112 responses (Table 5). The most important problemsindicated werethat cover cropping interferes with spring field work and/ or fall harvest (interferences in spring and fall were cited in equal numbers) and that growers sometimes experience difficulty with incorporating or plowing under a cover crop. Cost in labor, materials and equipment were frequently noted as drawbacks.

EXTENDING information. Fortyfour percent of respondents find Cornell Cooperative Extension very useful as a source of information, and an additional $36 \%$ find extension some-

Table 3. $\mathrm{N}$ umber of respondents growing vegetables and most common cover crops.

\begin{tabular}{lccccc}
\hline Vegetable & \multicolumn{5}{c}{ C over crop } \\
crop & Wheat & R ye & O ats & Clover & B arley \\
\hline Potatoes & 2 & 9 & 4 & 3 & 2 \\
Onions & 2 & 8 & 2 & 1 & 6 \\
Lettuce or leafy greens & 1 & 12 & 4 & 2 & 1 \\
Cucurbits (not pumpkins) & 9 & 25 & 9 & 5 & 1 \\
Pumpkins & 7 & 26 & 6 & 4 & 2 \\
Peppers & 7 & 19 & 7 & 5 & 1 \\
Tomatoes & 9 & 26 & 7 & 3 & 2 \\
D ry beans & 5 & 8 & 3 & 8 & 1 \\
Beets or carrots & 5 & 14 & 6 & 3 & 3 \\
Peas & 13 & 18 & 9 & 1 & 1 \\
Snap beans, processing & 9 & 5 & 6 & 7 & 1 \\
Snap bean, fresh market & 2 & 13 & 2 & 4 & 3 \\
Sweet corn, processing & 9 & 7 & 8 & 2 & 2 \\
Sweet corn, fresh market & 9 & 26 & 7 & & 2 \\
Cabbage & 10 & 18 & & & 2 \\
\hline
\end{tabular}


T able 4. Benefits of using cover crops as indicated by respondents; 219 total responses were given. B enefits representing $<1 \%$ of responses are not shown.

B enefits of using cover crops indicated by respondents

E rosion control, including windbreaks for wind erosion

Adds organic matter

Weed control

Adds or conserves nutrients such as nitrogen

I mproves soil tilth, makes plowing easier

Reduces soil compaction

Reduces insect and disease pressure

Conserves soil moisture

Produces better crop growth and yield

Conserve water quality and reduce runoff

what useful as a source. Growers were most interested in receiving cover crops information in written form: $35 \%$ selected "newsletter article" and 23\% selected "bulletin" as the preferred method for conveying the information, compared to $14 \%$ who selected "grower meeting."

In the Additional Comments section of the survey, respondents madea wide variety of comments on research, information, and technical needs. Several mentioned that they have been using cover crops for many decades. With the exception of those using sudangrass, veryfew growersareplanting cover crops other than conventional small grains and legumes. $\mathrm{H}$ owever, five growers specifically requested more research and information on alternative cover crops such as hairy vetch, mustards (Brassica juncea $L$. and B. hirta M oench), fescues (Festuca sp.), and sudangrass. Several also wanted to know more about how different cover crops affect weeds, diseases, and insect pests of vegetable crops. O thers asked for information on integrating cover crops into their specific cropping practices, such as options for late seeded cover crops, potential herbicide effects in interseeding legumes in sweet corn, and options for perennial crops.

SURVEY OF ONION GROWERS. In the survey of onion growers, nine indicated that they now regularly use sudangrass or sorghum-sudangrass hybrid cover crops in rotation with onions. Of these nine, three began growing sudangrass cover crops in the mid-1980s, when the first cooperative extension trial with sudangrass was conducted in the area. The remaining six growers have begun using sudangrass since 1995. In 1997, >200 acres (81 ha) of sudangrasswereplanted on muck soils in the surveyed area. R esponse (\%) 25

and $91 \%$ to $97 \%$ of onion growers in $\mathrm{N}$ ew York State planted cover crops. In that study, adoptors of integrated pest management (IPM) were somewhat more likely to cover crop than nonadoptors.

The apparent trend that producers with larger vegetable acreage are morelikely to grow cover cropsmay be explained by their greater opportunity to rotate acres away from cash crop production and put it into cover crops. $\mathrm{H}$ owever, the average number of cover cropped acres per size class (Fig. 1) tends to fall from the median [ 13 acres (5.3 ha) in the 1 to 25 acre class] toward the minimum [ 956 acres (387 ha) in the 1001 to 4000 acre class] of each size class as vegetable acreage increases. This suggests that while large-scale growers may be more likely to cover crop at least some portion of their acreage, smaller scale growers may be devoting a larger percentage of their acres to cover crops.

Cover crop speciesselection would be expected to vary regionally. I $\mathrm{n}$ contrast to western $\mathrm{N}$ ew York, growers in $M$ aryland grow very little oats as a cover crop ( $M$ aryland $D$ epartment of Agriculture, 1997). H owever, similar to $\mathrm{N}$ ew York, small grains are still the dominant type of cover crop grown in $M$ aryland, with rye, wheat, and barley being the predominant species.

Legumes are of much less significance than small grains in N ew York, and are comprised almost exclusively of clover. Red clover is often frostseeded into wheat grown as a cash crop, allowed to grow after wheat harvest in July, and incorporated the following spring. Thistakes advantage of an otherwisefallow period during warm growing conditions following wheat harvest. Wheat is a common rotation crop for vegetables in this region, and

Table 5. Problems with using cover crops as indicated by respondents; 112 total responses were given. Problems representing $<1 \%$ of responses are not shown.

Problems with using cover crops indicated by respondents

R esponse (\%)

Interferes with spring field work and/ or fall harvest

Difficulty with incorporating cover crop or plowing

31

Too costly (labor, materials, and/ or equipment)

25

Retains soil moisture and limits soil warming in spring

14

None

Weed or insect problems

$\mathrm{N}$ ot compatible with weed control program

Cover crop doesn't winter kill

Not enough growth

Finding source for seeds

Robs soil of moisture for cash crop
9

4

3

3

3

2

2

Horthechnology • July-September 1999 9(3) 
may beused either as a cover crop (i.e., incorporated rather than harvested) or a cash grain crop, depending on market prices and other factors. Even if used as a cash grain, a wheat crop usually provides excellent erosion protection over the winter (Bellinder and Gaffney, 1995). Because survey respondents were not given a specific definition of the term cover crop, it is likely that some acres reported here as wheat cover crops may have been harvested, and that not all wheat planted by respondents was reported here as a cover crop. Similarly, alfalfa is rarely grown simply as a cover crop, but as a rotation crop which is mowed for harvest. Alfalfa requires at least a year and a half for establishment and significant growth, making it a very expensive cover crop choice.

$\mathrm{O}$ ats, the most predominant cover crop in terms of acreage, are planted mostly in September and O ctober, and typically winter kill, leaving an easily tillable surface residue (StiversYoung, 1998). Grain rye is the most predominant cover crop in terms of numbers of growers, especially among fresh market vegetable producers. This is probably because rye can be planted later in the season (through much of $O$ ctober) than other cover crops and still result in significant groundcover. Barleyisused primarily by onion growers as a wind break at onion seeding, and is typically killed using a selective herbicide within a month of planting.

As vegetable production systems change in response to technological, demographic, economic and other factors, the use of less well known covercrop species may become more appropriate. Advances in crop breeding may improve the agronomic characteristics or pest-suppressive effects of cover crops previously deemed unsuitable for widespread use. O ver the past 5 years, a number of $\mathrm{C}_{\text {ornell }} \mathrm{C}$ ooperative Extension research projects and educational programs have focused on new cover crop species including hairy vetch, sudangrass, sorghum-sudan hybrids, and various brassica cover crops such as Indian mustard (Brassica juncea L.), yellow mustard (Brassica hirta M oench) and oilseed radish ( $R$ aphanus sativus $L$. var. oleifera). Sudangrass and hairy vetch were once commonly used in $\mathrm{N}$ ew York (Barron, 1925) while the use of brassicas as cover crops is new. The adoption of sudangrass and sor- ghum-sudan hybrids among onion growers, the major targeted audience, has been relatively high, especially considering that valuable land must be taken out of production for an entire year. M ost growers have adopted the practice recently, likely responding at least in part to extension programs. Research on brassica cover cropsis still ongoing, and only a handful of producers across the state have experimented with these. H owever, there seems to be potential in focusing extension effortson the ad option of hairy vetch, which has been field tested repeatedly in the northeastern U.S. (M angan and Herbert, 1992), and may provide different benefits than small grains (Wagger et al., 1998). O ne obstacle to the adoption of hairy vetch is the cost of seed, which can be as much asthree times the cost of small grain cover crops on a per acre basis (M allory et al., 1998). Growers can produce their own seed relatively easily, although land producing seed is not available to produce vegetables.

The benefits of cover cropping identified by growers in this survey (Table 4) are consistent with reportsof growers' reasons for cover cropping in other regions of the country. A small number of cash grain farmers cooperating in on-farm research in W isconsin identified erosion control as the leading reason that they considered using cover crops (M allory et al., 1998), as did farmers in the $M$ aryland study ( $M$ aryland D epartment of Agriculture, 1997). Wisconsin farmers also indicated that $\mathrm{N}$ benefits were an important factor in their decision, although the economic analysis of the cover cropping practices used in that study indicated that cover crop $\mathrm{N}$ was at least three times as expensive as fertilizer $\mathrm{N}$. Costs, both direct and indirect, were the most important concern expressed by these farmers. M aryland farmers also identified improvements in soil tilth as an important effect of planting cover crops.

The identified benefits are also attainable with the predominant cover crops used by these producers. Erosion control and the addition of organic matter were the most important benefits identified by this population of growers, and these are both very important concerns for vegetable soils in $\mathrm{N}$ ew York (Wolfe et al., 1998). Small grain cover cropsarewell known for their ability to control erosion
(Langdale et al., 1991) and supply organic carbon (Reicovsky and Forcella, 1998).

No grower specifically mentioned the improvement of soil biological activity as a benefit of using cover crops. Thisis a difficult characteristic for producers to assess but has recently been recognized as a very important component of soil quality (Romig et al, 1995; Walter et al., 1997). I ncreasing the use of $\mathrm{N}$-rich legume cover crops relative to carbonaceous small grains may help growers improve the biological activity of their soils, beyond effectsof added nitrogen from legumes (Andren et al., 1988; Wagger et al., 1998). In addition, while only three respondents mentioned the conservation of water quality and runoff reduction, small grain cover crops are probably significantly contributing to cleaner surfaceand groundwater where they are being used (Staver and B rinsfield, 1998; M eisinger et al., 1991). This benefits not just area producers, but society as a whole.

IMPLICATIONS FOR RESEARCH AND EXTENSION. This study has provided evidence that producers in N ew York value the information and expertise offered by cooperative extension, and do adopt new practices in response to Extension programs. Results of this survey point out a number of further opportunities for research and extension efforts toward the adoption of appropriate cover crops and improvement of cover crop management among commercial vegetable growers in $\mathrm{N}$ ew York.

- M oreresearch and demonstrations are needed on newer cover crops such as hairy vetch, brassicas, and sweet clovers (M elilotus sp.) to better understand their potential suitability to N ew York growers. Information on how these and other cover crops perform in mixtures compared to monocultures would also be useful. Participatory research approaches actively involving growers may speed appropriate adoption of these cover crops.

- M any growers identified interference with fall harvest as a significant problem, and late vegetable harvest is undoubtedly an important obstacle in greater adoption of cover cropping in this region. $M$ ore research and demonstrations should be conducted on ways to 
get cover crops established earlier in the fall without interfering with vegetable crop harvests, such as overseeding or late interseeding.

- Research on ways to mechanically and/ or chemically manage cover crops in spring to minimize the interferencewith spring field work and ease incorporation may facilitate further adoption.

- Educational programs should be designed with the understanding that the cover crop needs of small farmers may be different from those of larger farmers. The objective for small farms might be to simply get started growing cover crops, whiletheobjectivefor larger farms might be to find ways to expand acreageal ready being cover cropped. Written materialsremain useful methods for conveying cover crops information to farmers.

- Society benefits from the environmental stewardship practices of area growers. G reater efforts should be made to educate the general public about these benefits.

\section{Literature cited}

Andren, O., K. Paustian, and T. Rosswall. 1988. Soil biotic interactions in the functioning of agroecosystems. Agr. E cosyst. Environ. 24:57-67.

Barron, J.H . 1925. The utilization of legumes in the rotation. A. East. Agron. J. 17(7):380-389.

Bellinder, R.R. and F.B. Gaffney. 1995. Erosion control in cropsthat producesparse residue, p. 68-79. In: B.L. Blevins and W.C. M oldenhauer (eds.). Crop residue management to reduce erosion and improve soil quality, Appalachian and $\mathrm{N}$ ortheast. U SD A-ARS Conservation Res. Rpt. 41.

Blevins, R.L., J.H. Herbek, and W.W. Frye. 1990. Legumecover crops asanitrogen source for no-till corn and grain sorghum. Agron. J. 82:769-772.

Bruce, R.R., P.F. H endrix, and G.W. Langdale. 1991. Role of cover crops in recovery and maintenance of soil productivity, p. 109-115. In: W.C. H argrove (ed.). Cover crops for clean water. Soil Water Conservation Soc., Ankeny, I owa.
Creamer, N .G., B. Plassman, M .A. Bennett, R.K.Wood, B.R. Stinner, and J. Cardina. 1995. A method for mechanically killing cover crops to optimize weed suppression. Amer. J. Altern. Agr. 10:157-162.

D rinkwater, L.E., P. Wagoner, and $M$. Sarrantonio. 1998. Legume-based cropping systems have reduced carbon and nitrogen losses. N ature 396:262-265.

Drost, D., G. Long, and K. H ales. 1997. U tah's vegetable growers: assessing sustainable agriculture. H ortT echnology $7(4): 445-450$.

D uff, S.N ., D.P. Stonehouse, S.G. H ilts, and D.J. Blackburn. 1991. Soil conservation behavior and attitudes among $\mathrm{O}$ tario farmers toward alternative government policy responses. J. Soil Water Conservation 46:215-219.

Glynn, C.J., D.G. McDonald, and J.P. Tette. 1995. Integrated pest management and conservation behaviors. J. Soil Water Conservation 50(1):25-29.

L angdale, G.W., R.L. Blevins, D.L. Karlen, D.K. M cCool, M.A. N earing, E.L. Skidmore, A.W. Thomas, D.D. Tyler, and J.R. Williams. 1991. Cover crop effects on soil erosion by wind and water, p. 15-22. In: W.C. H argrove (ed.). Cover crops for clean water. Soil Water Conservation Soc., Ankeny, I owa.

M allory, E.B., J.L. Posner, and J.O. Baldock. 1998. Performance, economics, and adoption of cover crops in Wisconsin cash-grain rotations: 0 n-farm trials. Amer. J. Altern. Agr. 13(1):2-11.

M angan, F.X. and S.J. H erbert. 1992. L egume cover cropsfor vegetable production. Proceedings of the 1992 N ew York State Vegetable and Direct $M$ arketing Conference. Syracuse, N.Y. p. 47-48.

$M$ aryland Department of Agriculture. 1997. A survey of M aryland farmers' winter cover crop participation. Annapolis, Md.

M eisinger, J.J., W.L. H argrove, R.L. Mikkelson, J.R. Williams, and V.W. Benson. 1991. Effect of cover crops on groundwater quality, p. 57-68. In: W.C. $\mathrm{H}$ argrove (ed.). Cover crops for clean water. Soil Water Conservation Soc., Ankeny, lowa.

Mishanec, J. 1998. Conclusions from 5 yearsof sorghum sudangrassresearch. Proceedings of the 1998 New York State VegetableC onferenceand N ew York State Berry G rowers M eeting. Syracuse. p. 194196.
N.Y. Agricultural Statistics Service. 1997. New York agricultural statistics, 19961997. N .Y. Agr. Stat. Serv., Albany.

Pieters, A.J . 1927. G reen manuring. Principles and practices. Wiley, N ew York.

Reicovsky, D.C. and F. Forcella. 1998. Cover crop and soil quality interactions in agroecosystems. J. Soil Water Conservation 53(3):224-229.

Romig, D.E., M.J. Garlynd, R.F. H arris, and $\mathrm{K}$. M cSweeney. 1995. H ow farmers assess soil health and quality. J. Soil Water Conservation 50(3):229-236.

Sainju, U .M . and B.P. Singh. 1997. Winter cover crops for sustainable agricultural systems: I nfluence on soil properties, water quality, and crop yields. HortScience 32:21-28.

Staver, K.W. and R.B. Brinsfield. 1998. $U$ sing cereal grain winter cover crops to reducegroundwater nitratecontamination in the mid-Atlantic coastal plain. J. Soil Water Conservation 53(3):230-240.

Stivers-Young, L.J . 1998. Growth, nitrogen accumulation, and weed suppression by fall cover crops following early harvest of vegetables. H ortScience 33(1):60-63.

U.S. D epartment of Commerce. 1994. 1992 Census of agriculture. vol. 1. Geographic area series. Part 32. N.Y. Bur. Census, Econ. Stat. Admin., Wash., D.C.

Viane, N .M . and G.S. Abawi. 1998. M anagement of $M$ eloi dogynehapla on lettucein organic soil with sudangrass as a cover crop. Plant D is. 82(8):945-952.

Wagger, M.G., M.L. Cabrera, and N.N. Ranells. 1998. Nitrogen and carbon cycling in relation to cover crop residue quality. J. Soil Water Conservation 53(3):214-218.

Walter, G., M. Wander, and G. Bollero. 1997. A farmer-centered approach to developing information for soil resource management: The Illinois soil quality initiative. Amer. J. Altern. A gr. 12(2):64-72.

Wolfe, D.W., D.T. Topoleski, N.A. Gundersheim, and B.A. Ingall. 1995. Growth and yield sensitivity of four vegetable crops to soil compaction. J. Amer. Soc. H ort. Sci. 120:956-963.

Wolfe, D.W., G.S. Abawi, H. van Es, L.J . Stivers, L.H. Pedersen, and D.I.Riggs. 1998. M anagement strategiesfor improved soil quality with emphasis on soil compaction: Final report. Cornell U niversity (Ithaca, N.Y.) D ept. Fruit Veg. Sci. Rpt. 72. 